\title{
TRANSFORMATIONAL LEADERSHIP: MILLENNIAL LEADERSHIP STYLE IN INDUSTRY 4.0
}

\author{
Umar Yeni Suyanto ${ }^{1}$, Mu'ah ${ }^{2}$, Ika Purwanti ${ }^{3}$, Mokhtar Sayyid ${ }^{4}$ \\ KH. Ahmad Dahlan Economics Institute of Lamongan \\ E-mail: umarsuyanto@gmail.com
}

\begin{abstract}
This article analyzes how transformational leadership roles reflect the character of the millennial generation in the fourth industrial revolution. As the development of technology advances rapidly, people take advantages of it not only for education and research development but also for need fulfillment. In industry 4.0, technological competition seems to have great impact on company performance. The data obtained from the Ministry of Communication and Information show that the growth of online retail business in Indonesia was relatively high (36\%) from year 2010 to 2013. The rate was twice higher than that of The Phillipine's and Malaysia's, even 3.5 times higher than Singapore's. The number of Internet users in 2014 was 83.6 millions, which showed approximately $33 \%$ growth rate in Internet penetration. The Central Statistics Agency (BPS) reports that $50 \%$ of workers in Indonesia are less than 30 years old. In other words, the millennials are mostly active workers who have constant access to information and technology. This is a library research gathering and analyzing information from related references and theories, which have become the basic foundation and sources in analyzing problems in this research. The results revealed that transformational leadership can be improved and optimized by implementing the four primary factors, namely idealized influence, intellectual stimulation, inspirational stimulation, and individualized consideration.
\end{abstract}

Keywords: industry 4.0, millennial, transformational leadership

\section{INTRODUCTION}

Companies competing in industry 4.0 seem to experience rapid growth in Indonesia, especially Ecommerce-based companies. Data by the Ministry of Communication and Information show that since 2013, Indonesia's E-commerce-based industry continued to grow signicantly, with the average value of total E-commerce transactions of $0.9 \%$ per year. There seems to be a great opportunity here as indicated by online retail businesses in Indonesia that grew at relatively high rate $(36 \%)$ between 2010 and 2013. The rate was twice higher than that of The Phillipine's and Malaysia's, even 3.5 times higher than Singapore's. Indeed, an E-commerce business is likely to have good potential in Indonesia by looking at the following figures. It has big population of about 250 million, 83.6 million Internet users in 2014 with $33 \%$ growth rate in Internet 
penetration, 71 million smartphone users, and USD 1.2 billion digital sales \& advertising (Ministry of Communication and Information, 2014).

To complement the figures, The Central Statistics Agency (BPS) shows that $50 \%$ of workers in Indonesia are less than 30 years of age, which means that the millennials are mostly active workers who have constant access to information and technology. With the ample opportunity suggested by this statistics, creativity and innovation are the key to winning industrial competition in Indonesia. In this case, leaders undoubtedly have an overarching role in the competition and achievement of the company.

Cheung (2014) states that transformational leadership would inspire employees to optimize their skills and abilities to provide better services or tasks. Meanwhile, Ilias \& Pappas (2016) explain that the difference between conventional industries and ICT-based industries lies in the consumer's motivation. In ICT-based industries, consumers tend to look for competitive prices, product promotions, shopping convenience, interaction with the site, personal service, the quality of the service they receive, perceived value, and availability of information as a determinant of their purchase. These encourage companies in the fourth industrial revolution to continuously create innovations by increasing their creativity in various aspects. In this case, leaders have prominent role in directing, supervising and evaluating the innovations and creative products brought by the employees.
This article examines the relationship between transformational leadership styles in optimizing the potential of the millennial generation in the fourth industrial revolution and the role of transformational leadership in facing the technological era in Indonesia. The authors use Bernard \& Bass' theory as the basis of the problem analysis. Also, the development of the theoretical approach tailored to the conditions of the companies competing in industry 4.0 will be examined.

\section{LITERATURE REVIEW}

Transformational leadership style is often deemed effective in motivating employees to show expected behavior. According to Bernard \& Bass (2009) and Buntara (2013), there are three ways that can be adopted by a leader who chooses transformational leadership styles: 1) encourage employees to be more aware of the importance of business outcomes, 2) encourage employees to prioritize group interests over individual ones, and 3) pay more attention to employees' self-esteem and self-actualization.

D.A. Aga et al. (2016) mention there are four dimensions of transformational leadership, namely idealized influence, intellectual stimulation, inspirational motivation, and individualized consideration. In a similar vein, Munevver (2015) asserts that these dimensions of transformational leadership have specific function in the transformation process. The idealized influence emphasizes trust, values and ethics, while inspirational motivation means leaders give 
meaningful and challenging tasks for the employees and uplifts their spirit and optimism. Another dimension of transformational leadership is intellectual stimulation, in which the leader challenges old assumptions, beliefs and traditions and encourages new ways of thinking. The four and final dimension is individualized considerations, in which the leader identifies the needs, abilities and aspirations of the followers through coaching and supervision.

Furthermore, it is stated that in transformational leadership, the leader has a good vision to increase his followers' spirit and expectations through approaches based on awareness, sense of belonging, as well as the ability to provide support, encouragement and guidance to maximize his followers' potential. In short, a leader who can build a solid team with strong work ethic is a transformational leader.

The role of transformational leaders is pertinent to the formulation of strategies implemented by the company. It is supported by Hyväri (2015), who states that strategies formulation involves formulating and implementing the main objectives and initiatives taken by the company's top management on behalf of the owner, based on considerations by human resources as well as internal and external assessment. For companies competing in the fourth industrial revolution, strategy is the key to success. This is in accordance with the standpoint of Jing Elaine (2013), which maintains that strategy formulation is very significant for companies because it provides a framework for operational planning, increases organizational effectiveness, and gives the direction of organizational activities which help the organization reap long-term benefits.

One of the important phenomena in the globalization era is the birth of the gadget generation- a term used to mark the emergence of the millennial generation. Gadgets mean devices, thus the gadget generation refers to a generation who lives side by side with technological devices. In other words, the devices are inseparable parts of their lives. Indeed, high-tech gadgets become an integral part of the millennial generation (Zuhal, 2000; Naisbitt, 2002).

According to Severin and Tankard (2005), a number of studies on the impact and use of the Internet show that the Internet is the main source for learning about many things, including what is currently happening in the world, entertainment, fun, and relaxation. What's more, it is where many people try to forget their problems, overcome loneliness, spend their time, and do things with friends or family. The Internet has plenty benefits, especially for communication and information search. The benefit is enjoyed by the society, not to mention teenagers. Through the Internet, information can be accessed instantly (e.g. using Google or other search engines). Teenagers even use the Internet to make friends, chat, send emails, and even find references for their school assignments.

Millennial generation refers to a generation born between 1977 and 1994. An important phase in the life 
of the millennial generation is the technological advancement that has been an integral part of everyday life (Shiffman \& Kanuk, 2007). Some characteristics of this generation include higher level of education, better knowledge, and more diverse ethnicity compared to the previous generation. The millennial generation is often referred to as echo-boomers or millennium generation. The term 'echo-boomers' was coined to mark the era where it was born (during World War II), while the term 'millennium generation' was created in relation to the advancement of technology and the coming of millennium era in which this generation grows up.

Some traits of the millennial generation include being dependent on the Internet, having high confidence, displaying high selfesteem, and being more open to and tolerant of change (Kilber, et al., 2014). The study by Huybers (2011) shows salaries, individual recognition, flexibility in work schedules, and career advancement are indispensible for millennials. Besides, job satisfaction of the millennial generation is determined by intrinsic factors such as opportunities for organizational ownership, training, perceptions toward supervisor support, varied and meaningful work, and work-life balance (Solnet and Hood, 2008).

The history of the industrial revolution starts from industry 1.0, 2.0, 3.0, to industry 4.0. The industrial phase is a real change. Industry 1.0 was characterized by mechanization of production for the effectiveness and efficiency of human activities; industry 2.0 introduced a mass production and quality standardization; and industry 3.0 initiated overall adjustment and flexibility of automated manufacturing as well as robotics in manufacturing. Then industry 3.0 was replaced by Industry 4.0, which encompasses cyber physical system and collaborative manufacturing (Hermann et al., 2015 and Irianto, 2017).

According to Lee et al. (2013), industry 4.0 is marked by an increase in manufacturing digitalization encouraged by four factors: 1) increased data volume, computing power, and connectivity; 2) the emergence of analysis, capability, and business intelligence; 3) the occurrence of new forms of interaction between humans and machines; and 4) the improvement of instructions to bring digital ideas into the physical world (e.g. robotics and $3 \mathrm{D}$ printing).

Lifter and Tschiener (2013) mention that the basic principle of industry 4.0 is the integration of machines, workflows, and systems by applying intelligent networks along the chain and the production process. According to Hermann et al., (2016) there are four design principles of industry 4.0. First, interconnection, that is, the ability of machines, devices, sensors, and people to connect and communicate with each other through the Internet of Things (IoT) or the Internet of People (IoP). This principle comprises collaboration, standards, and security.

The second design principle is information transparency. It refers to the ability of the information system to create virtual copies of the 
physical world by enriching digital models with sensor data, including data analytics and information provision. The next design principle is technical assistance, which includes: (a) the ability of the assistance system to support humans by combining and evaluating the information consciously to make the right decisions and solve problems immediately, (b) the ability of the system to support humans by carrying out unpleasant, tiresome, or unsafe tasks, (c) visual and physical assistance.

The last design principle of industry 4.0 is decentralized decisions. It encompasses the ability of virtual systems to make their own decisions and carry out tasks as effectively as possible. These four design principles of industry 4.0 by Hermann et al., (2016) are summarized in Figure 1.

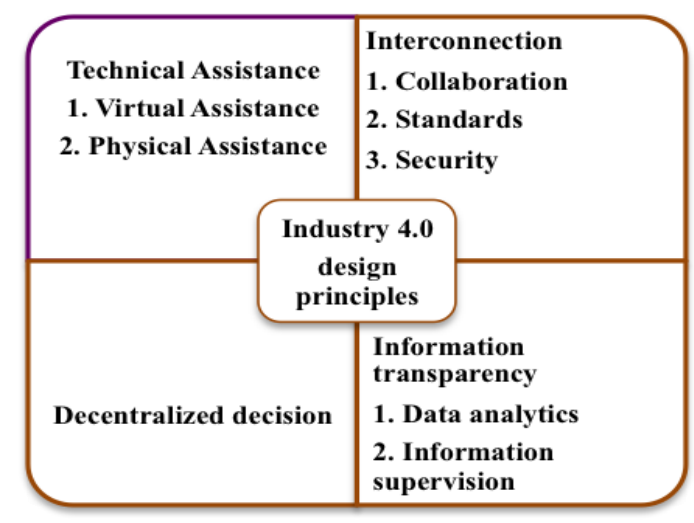

Figure 1. Industry 4.0 design principles Source: Hermann et al., 2016

Industry 4.0 has introduced a more flexible mass production technology (Kagermann et al. (2013). The machine will operate either independently or in cooperation with humans (Sung, 2017). Industry 4.0 is an approach to control the production process by synchronizing time through production integration and adjustment (Kohler \& Weisz, 2016). On top of that, Zesulka et al. (2016) add, industry 4.0 design principles are used in these three interrelated aspects: 1) digitalization and transformation from economic interaction using simple techniques to economic networks using complex techniques, 2) digitizing products and services, and 3) new market models.

Baur and Wee (2015) introduce the term "digital compass" for industry 4.0 as seen in the diagram as seen on the Figure 2. 


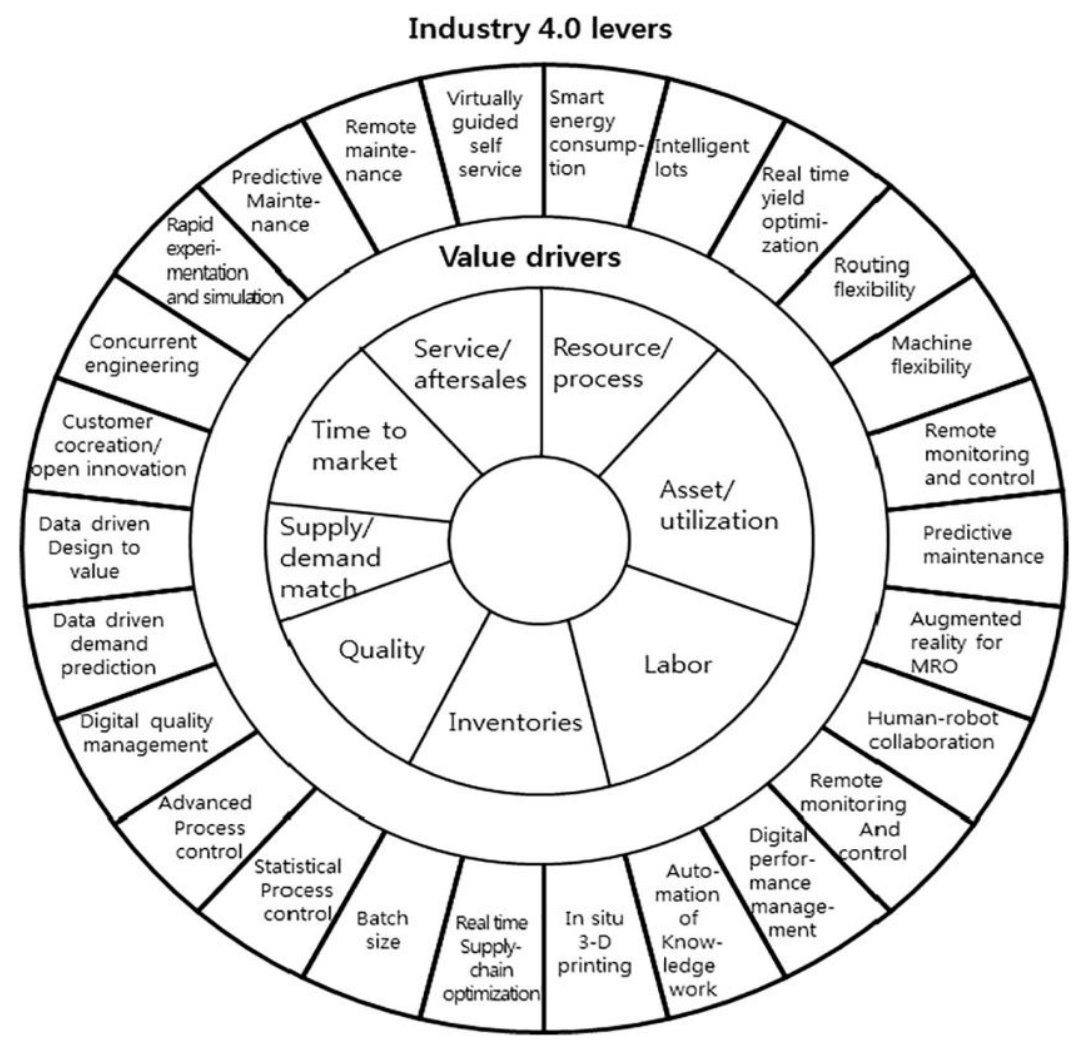

Figure 2. Industry 4.0 levers

Source: Baur \& Wee, 2015

Figure 2 displays an instrument for companies to implement industry 4.0 to fit their needs. In this case, labor force must meet the following criteria: 1) human - robot collaboration, 2) control and remote control, 3) digital performance management, and 4) work knowledge automation.

One of the implementations is by replacing human labor power with robots to make a cheaper, effective, and efficient production. Indeed, technological advancement has allowed automation in many different fields. New technologies and approaches combining the physical, digital, and biological worlds will fundamentally change the patterns of life and human interaction (Tjandrawinata, 2016).
As a period of technological revolution, Industry 4.0 changes the way human do activities in terms of scale, scope, and complexity and brings new transformation. Undoubtedly, humans will likely to live in global uncertainty, and therefore the ability to predict a rapidly changing future is substantial. Every country must respond to these changes in an integrated and comprehensive manner. It should involve all global political stakeholders in public \& private sector, academia, and civil society, so the challenges of industry 4.0 can be embraced and seen as opportunities.

Sung (2017) identified the challenges of industry 4.0 as follows: 1) information technology security 
issues, 2) reliability and stability of production machines, 3) lack of necessary skills, 4) stakeholders' reluctance to change, and 5) job losses in many sectors as a result of automation.

\section{METHOD}

This is a library research gathering theoretical references relevant to transformational leadership and millennial characteristic issues in industry 4.0. The theoretical references were sought through international reputable journals and books that were considered relevant. The aspects identified from the literature include: criteria for transformational leadership, millennial characteristics, and industry 4.0 model.

\section{RESULT AND DISCUSSIONS}

A transformational leader who can maximize the potential of the organization to achieve the common goal makes transformational leadership an alternative and a new breakthrough for industrial progress in Indonesia. Thi Thu Nguyen et al., (2016) argue that transformational leaders uplift the spirit and optimism of their followers, so they are inspired to achieve higher and focus more on common goals. Maryam (2016) believes that organizations with creative employees tend to create added value and maintain competitive advantage, especially in the dynamic business environment.

As previously presented in the "digital compass" by Baur \& Wee (2016) (see figure 2), the combination of human resources, information, and technology is the basic formula in executing managerial functions. This certainly impacts positively on strategic decision making in the company or organization. It is when transformational leadership is implemented optimally in industry 4.0 that great advantages can be obtained by the industry or the company. Below are potential advantages of optimizing opportunities in industry 4.0

Table 1. Potential advantages of Industry 4.0

\begin{tabular}{ll}
\hline \multicolumn{1}{c}{ Author } & \multicolumn{1}{c}{ Potential advantage } \\
\hline (Lasi et al.,2014) & $\begin{array}{l}\text { More rapid development of products, customization of products based } \\
\text { on individual demand, more flexible and quicker response in the } \\
\text { production, resource efficiency }\end{array}$ \\
(Rüßmann, et al., 2015) & $\begin{array}{l}\text { Improved productivity, enhanced growth of revenue, increased } \\
\text { demand for skilled labor, increased investment }\end{array}$ \\
(Schmidt et al., 2015) & $\begin{array}{l}\text { Realization of mass customized products, utilization of idle data, } \\
\text { improvement in production time }\end{array}$ \\
(Kagermann et al.,2013) & $\begin{array}{l}\text { Fulfillment of customers' individual needs, more dynamic business } \\
\text { and engineering process, more optimal decision-making, emergence of } \\
\text { new business models, new ways of creating added value } \\
\text { Realization of more efficient, smart and customizable manufacturing } \\
\text { process at a reasonable cost }\end{array}$ \\
\hline
\end{tabular}

From Table 1 above, it can be seen that the advantages of industry 4.0 can be optimized by implementing transformational leadership style suitable for current needs. BPS announced that $50 \%$ of workers in Indonesia are under 30 years of age, which means that the 
millennials are mostly active workers who have constant access to information and technology. Clearly, if managed properly, it can become both opportunity and challenge for the company to win competition in the fourth industrial revolution. As Dalegonare et al., (2018) states, the concept of Industry 4.0 allows companies to have flexible manufacturing processes, analyze large data in a short time, and improve strategic \& operational decision making.

Most of the industrial workers are millennial generation. Indeed, it is a great opportunity because this group has immediate and regular access to information. Kyung Sung (2018) suggests that to maximize the potential advantages of Industry 4.0 and provide added value to the company, leaders must take account of the indispensible role of information. Kamble et al., (2018) confirms that Industry 4.0 promises to advance organizations or companies toward the digital decade. Indeed, developing a strong ecosystem in the infrastructure, extra structure and superstructure is of importance, so the skill development and policy making become the key to win the competitions in industry 4.0. Lezzi (2018) argues that competition will be increasingly stringent because more and more companies are adopting industry 4.0 paradigm (also known as Industrial Internet of Things). For this reason, and also considering the aforementioned results of previous studies, the role of leaders in managing and maximizing the involvement of the millennial generation in advancing the company is paramount. In this case, transformational leadership can be a great option in exercising sustainable leadership, as shown in figure 3 below

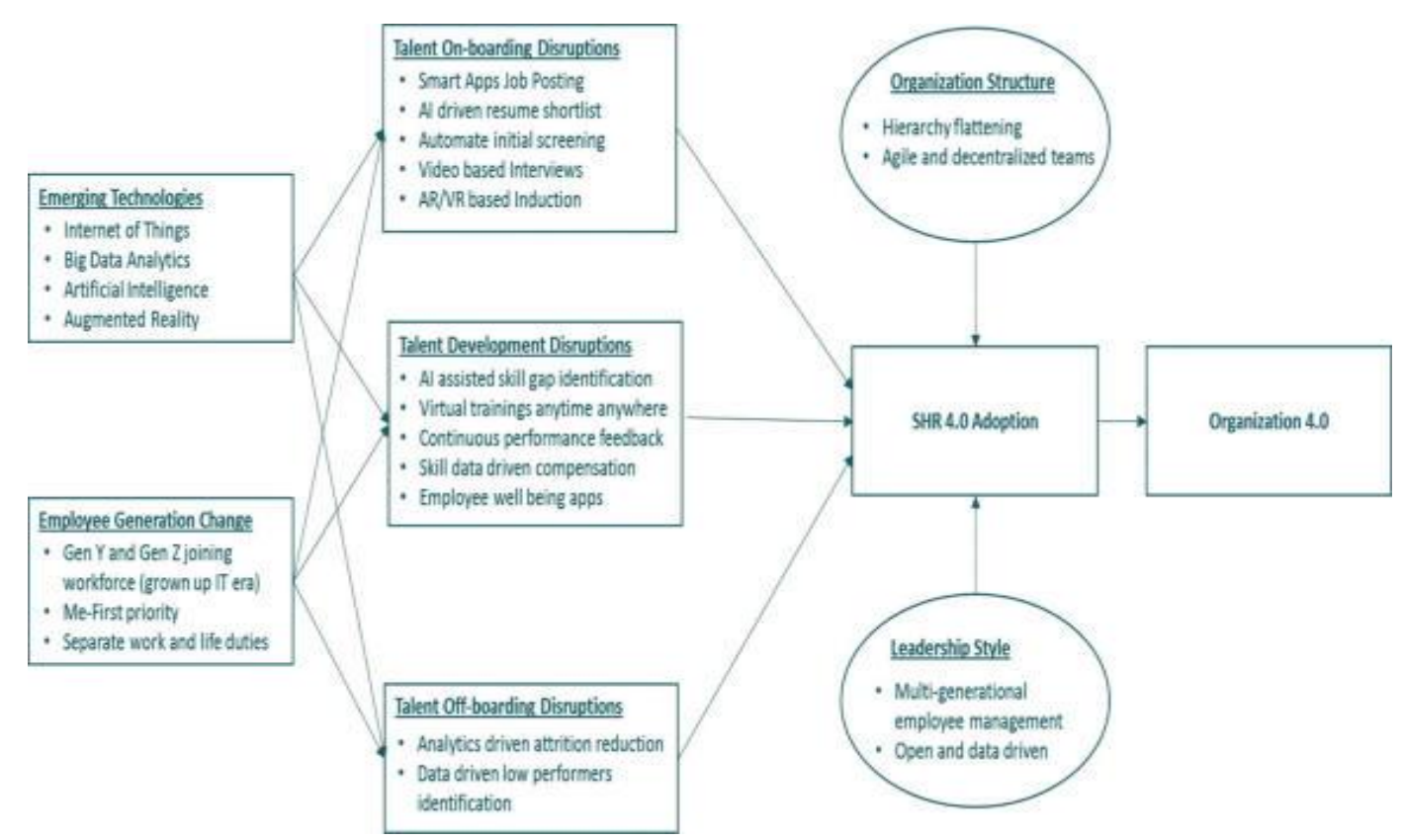

Figure 3. Smart 4.0 Framework

Source : Sivathanu \& Pillai, 2018 


\section{CONCLUSION}

Transformational leadership can help millennial generation play their roles optimally in the organization or company where they work. This leadership style emphasizes inspirational principles and support for the development of human resources. This is very useful to ease the adaptation to constant changes resulting from the advancement of information technology in industry 4.0. Also, transformational leadership is suitable for organizations with dynamic environment that requires a high level of creativity and innovation.

\section{REFERENCES}

Bass, B., \& Riggio, R. 2009. Transformational leadership. Mahwah, NJ: Lawrence Erlbaum Baur, C. \& Wee, D. (2015). Manufacturing's next act?. McKinsey \& Company.

Buntara, Egrita. 2013. Hubungan antara Kepemimpinan Transformasional, Budaya Organisasional, Komunikasi Organisasi, terhadap Kinerja Pegawai.www.bppkdepkeu.go.idl .../249 - hubungan - antara kepemimpinan transformasional. Chung-Jen Wang, Huei-Ting Tsai, Ming-Tien Tsai. 2014. Linking Transformational Leadership And Employee Creativity In The Hospitality Industry: The Influences of Creative Role Identity, Creative Self-Efficacy, And Job Complexity. Fujian,

China: Wuyi University.(40), 79-89.

D.A. Aga, N. Noorderhaven \& B. Vallejo. 2016. Transformational
However, the expected outcomes of transformational leadership can only be achieved when the leader continuously inspire the employees to be more aware of the importance of the common goals and group interests, pays attention to the employees' self-esteem and selfactualization, gives meaningful and challenging tasks for the employees, uplifts their spirit, and encourages creativity. Also, and perhaps more importantly, a transformational leader needs to identify differing needs, abilities and aspirations when providing coaching and supervision.

Leadership and Project Success: The Mediating Role of TeamBuilding. Addis Ababa, Ethiopia: Ethiopian Civil Service University. (34), 806 818.

Dalenogare, Lucas Santos., Benitez, Guilherme Brittes., Ayala, Néstor Fabián., Frank, Alejandro Germán. 2018. The Expected Contribution of Industry 4.0 Technologies for Industrial Performance. International Journal of Production Economics. (204). 383-394.

De Dreu, C., \&Weingart, L. 2008. A Contingency Theory of Task Conflict and Performance in Groups and Organizational Teams. In M. West, D. Tjosvold, \& K. Smith (Eds.), International Handbook of organizational teamworkand cooperative working (pp. 151-166).

Hermann, M., Pentek, T., \& Otto, B. 2016. Design Principles for Industrie 4.0 Scenarios. 
62| MANAJEMEN BISNIS • VOLUME 9 No. $01 ・$ April 2019

ISSN (print) - $\underline{2089-0176}$ (online) $\underline{2655-2523}$

Presented at the 49th Hawaiian International Conference on Systems Science.

Huybers, Catherine M. 2011. The Recruitment and Retention of Generation Y. Partial Fulfillment of the Requirements for the Master of Science Degree Training and Development, the Graduate School University of Wisconsin-Stout. (unpublished).

Hyväri, Irja. 2015. Roles of Top Management and Organizational Project Management in The Effective Company Strategy Implementation. Finland: Aalto University School of Business. (226), 108-115.

Illias O, Pappas, Panus E.2016. The Interplay of Online Shopping Motivations and Experience Factors on Personalized ECommerce: A Complexity Theory Approach. Trondeimh, Norway: Universiy of Science and Technology Press.

Irianto, D. 2017. Industry 4.0; the challenges of tomorrow. Delivered in Seminar Nasional Teknik Industri, Batu-Malang.

Jing Elaine Chen A, Shan L. Pan B, Tao Hua Ouyang. 2013. Routine reconfiguration in traditional companies' e-commerce strategy implementation: a trajectory perspective. China: Beihang University. (51), 270-282.

Kagermann, H., Lukas, W.D., \& Wahlster, W. 2013. Final report: Recommendations for Implementing The Strategic Initiative Industrie 4.0. Industrie 4.0 Working Group.

Kamble, Sachin S., Gunasekaran, Angappa,.. Sharma, Rohit,. 2018. Analysis of The Driving and Dependence Power of Barriers to Adopt Industry4.0 In Indian Manufacturing Industry. Computers in Industry. 101. 107-119.

Kilber, J., Barclay, A., \& Ohmer, D. 2014. Seven tips for managing generation Y. Journal of Management Policy and Practice. 15: 4, 80-9.

Kohler, D, \& Weisz, J.D. 2016. Industry 4.0: The Challenges of The Transforming Manufacturing. Germany: BPI France.

Kyung Sung, Tae. 2018. Industry 4.0: A Korea Perspective. Technological Forecasting \& Social Change. 132. 40-45.

Lasi, H., Fettke, P., Kemper, H.G., Feld, T. \& Hoffmann, M. 2014. Industry 4.0. Business \& Information Systems Engineering, 6(4), p.239.

Lee, J., Lapira, E., Bagheri, B., Kao, H., 2013. Recent advances and trends in predictive manufacturing systems in big data environment.Manuf. Lett. 1 (1), 38-41.

Lezzi, Marianna,. Lazoi, Mariangela., Corallo, Angelo., Cybersecurity For Industry 4.0 In The Current Literature: A Reference Framework. Computers in Industry. 103. 9711.

Liffler, M., \& Tschiesner, A. 2013. The Internet of Things and The Future of Manufacturing. McKinsey \& Company.

Maryam Khoshlahna, Farzad. 2016. The Role of Organizational Agility and Transformational Leadership in Service Recovery Prediction. Ardabil, Iran: 
Islamic Azad University. (230), $142-149$.

Moeljono, Djokosantoso. 2012. 13 Konsep Beyond Leadership. Jakarta: PT Elex Media Komputindo.

Munevver Olcum Cetin, F. Sehkar Fayda Kinik. 2015. An analysis of Academic Leadership Behavior From The Perspective of transformational Leadership. Turkey:Istanbul Technical University. (2017), 519-527.

Naisbitt, John. et al. 2002. High Tech High Touch. Jakarta: Pustaka Mizan.

Neugebauer, R., Hippmann, S., Leis, M., \& Landherr, M. 2016. Industrie 4.0-From The Perspective of Applied Research. Procedia CIRP, Vol. 57, pp. 2-7.

Rüßmann, M., Lorenz, M., Gerbert, P., Waldner, M., Justus, J., Engel, P. \& Harnisch, M. 2015. Industry 4.0: The Future of Productivity and Growth in Manufacturing Industries. Boston Consulting Group, p.14.

Schiffman, Lean, Leslie Lazar Kanuk. 2007. Consumer Behavior. Seventh edition. New Jersey: Patience Hall International, Inc.

Schmidt, R., Möhring, M., Härting, R. C., Reichstein, C., Neumaier, P. \& Jozinović, P. 2015. Industry 4.0-Potentials For Creating Smart Products: Empirical Research Results. International Conference on
Business Information Systems, pp. 16-27.

Severin, W. J and Tankard, J.W. 2005.Communication Theories, Methods \& Uses in The Massa

Sivathanu, Brijesh \& Pillai, Rajasshrie. (2018). Smart HR 4.0 - How Industry 4.0 Is Disrupting HR. Human Resource Management International Digest. Doi 10.1108/Hrmid-04-2018-0059.

Solnet, David \& Hood, Anna. 2008. Generation $\mathrm{Y}$ as Hospitality Employees: Framing A Research Agenda. Journal of Hospitality and Tourism Management. 15:1, 59-68.

Sung, T.K. 2017. Industri 4.0: A Korea Perspective. Technological Forecasting and Social Change Journal, 1-6.

Thi Thu Nguyen, Lokman Mia \& LanitaWinata. 2016. Effect of Transformational-leadership Style and Management Control System on Managerial Performance. Australia: The University of Western Australia.

Tjandrawinata, R.R. 2016. Industri 4.0: Revolusi Industri Abad Ini Dan Pengaruhnya Pada Bidang Kesehatan Dan Bioteknologi. Jurnal Medicinus, Vol 29, No: 1.

Zesulka, F., Marcon, P., Vesely, I., Sajdl, O. 2016. Industry 4.0 An introduction in the phenomenon. IFAC- Papers Online. 8-12.

Zuhal. 2000. Visi Iptek Memasuki Milenium III. Jakarta: Penerbit Universitas Indonesia (UIPress). 